\title{
The importance of the human element in teaching the anatomical sciences
}

\author{
Doris George Yohannan ${ }^{1,3}$ (D) $\cdot$ R. Reshmi ${ }^{2,3}$ (D) $\cdot$ Michael Hortsch ${ }^{4}$ (I)
}

Received: 1 February 2022 / Accepted: 21 February 2022 / Published online: 26 February 2022

(c) The Author(s), under exclusive licence to Springer-Verlag France SAS, part of Springer Nature 2022

We read the article entitled "Integration of innovative educational technologies in anatomy teaching: New normal in anatomy education" by Dr. Patra and co-authors that was recently published in Surgical and Radiological Anatomy [4] with great interest and appreciation. We wholeheartedly agree that anatomy teachers should be encouraged to try out innovative educational technologies, many of which are featured in this comprehensive review [4]. The importance of technology for the teaching of the anatomical sciences in today's learning environment is undisputed, and these approaches have proven to be especially valuable during the still ongoing COVID-19 pandemic. However, we believe that important additional aspects need to be considered before accepting them as effective educational tools and more than temporary COVID-19 pandemic substitutions. We also feel that in the article the use of technology for teaching anatomy at some points is viewed in an over-optimistic light.

First, the validation of e-learning resources is of utmost importance before they should be widely adopted [5]. Are they serving the intended educational goals and do they help learners to achieve them? Not all e-learning resources and strategies that were reviewed by Dr. Patra and colleagues have been properly tested and, very likely, not all will pass the test of being adequate learning tools.

Another pivotal factor in the use of learning technologies is their acceptance by learners and teachers. This is a multifactorial process and a theoretical framework has been developed to describe it [2]. In the medical education context, the perception of relevance for the ultimate educational goal,

Doris George Yohannan

dorisgeorge54@gmail.com

1 Government Medical College, Konni, Kerala, India

2 Government T.D Medical College, Alappuzha, Kerala, India

3 Kerala University of Health Sciences, Thrissur, Kerala, India

4 Departments of Cell and Developmental Biology and of Learning Health Sciences, University of Michigan Medical School, Ann Arbor, MI, USA the ease of use and familiarity with the technology, as well as recommendations by teachers and peers are among key factors that have a major influence on the usage behaviour of medical learners.

Finally, their correct use is an important variable whether educational technologies support or hinder students' learning success. Many students will not have the experience and knowledge to always use new learning tools to their best advantage [3].

It should also be noted that the implementation of technology-based teaching tools is globally very uneven, with developing countries having a financial and experience disadvantage [1]. Therefore, some traditional learning resources, like textbooks, remain essential for supporting anatomy education in many parts of the world.

Without question, many of the technologies reviewed in the paper by Dr. Patra and his co-authors have the potential to claim a permanent role in anatomical education. However, even the most advanced educational technology is doomed to failure if it is not properly tested or not deemed valuable for its educational purpose. In addition, its correct use by the learning community is of central importance. Every didactic technological resource is conceived and created by human inventors and is ultimately used by human learners. It is this human element that will ultimately decide the success or failure of these new educational technologies.

\section{Declarations}

Conflict of interest The authors declare that they have no conflict of interest.

\section{References}

1. Barteit S, Guzek D, Jahn A, Bärnighausen T, Jorge MM, Neuhann F (2020) Evaluation of e-learning for medical education in 
low- and middle-income countries: a systematic review. Comput Educ 145:103726. https://doi.org/10.1016/j.compedu.2019. 103726

2. Davis FD (1993) User acceptance of information technology: system characteristics, user perception and behavioral impacts. Int J Man Mach Stud 38(3):475-487. https://doi.org/10.1006/imms. 1993.1022

3. Hortsch M (2015) "How we learn may not always be good for us"- do new electronic teaching approaches always result in better learning outcomes? Med Teach 37(6):507-509. https://doi.org/ 10.3109/0142159X.2014.1001341

4. Patra A, Asghar A, Chaudhary P, Ravi KS (2022) Integration of innovative educational technologies in anatomy teaching: new normal in anatomy education. Surg Radiol Anat 44(1):25-32. https://doi.org/10.1007/s00276-021-02868-6

5. Tamin RM, Bernard RM, Borokhovski E, Abrami PC, Schmid RF (2011) What forty years of research says about the impact of technology on learning: a second-order meta-analysis and validation study. Rev Educ Res 81(1):4-28. https://doi.org/10.3102/00346 54310393361

Publisher's Note Springer Nature remains neutral with regard to jurisdictional claims in published maps and institutional affiliations. 